\title{
Environmental drivers of the benthic macroinvertebrates community in a hypersaline estuary (Northeastern Brazil)
}

\author{
Direcionadores ambientais da comunidade de macroinvertebrados bentônicos \\ em um estuário hipersalino (Nordeste do Brasil)
}

Carlinda Railly Ferreira Medeiros ${ }^{1}$, Annyelle Kelly da Silva Costa $^{1}$, Caroline Stefani da Silva Lima ${ }^{1}$, Jacicleide Macedo Oliveira ${ }^{1}$, Marcos Medeiros Cavalcanti Júnior ${ }^{1}$, Maxciell Ricardo Azevedo da Silva ${ }^{1}$, Rafaela Santos Dias Gouveia ${ }^{1}$, José Iranildo Miranda de Melo ${ }^{1}$, Thelma Lúcia Pereira Dias ${ }^{1}$ and Joseline Molozzi ${ }^{1 *}$

${ }^{1}$ Programa de Pós-graduação em Ecologia e Conservação, Departamento de Biologia, Universidade Estadual da Paraíba - UEPB, Rua Baraúnas, 351, Bairro Universitário, CEP 58429-500, Campina Grande, PB, Brazil

*e-mail: jmolozzi@gmail.com

Cite as: Medeiros, C.R.F. et al. Environmental drivers of the benthic macroinvertebrates community in a hypersaline estuary (Northeastern Brazil). Acta Limnologica Brasiliensia, 2016, vol. 18, e4.

\begin{abstract}
Introduction: The estuarine community of benthic macroinvertebrates spatially varies in response to changes in environmental variables in these ecosystems. Understanding this variability helps our understanding the mechanisms structuring these communities. Aim: Assess the structural aspects of the benthic macroinvertebrate community in a hypersaline estuary, and to relate to environmental variables that influence the community structure along the estuary. Methods: The study was conducted at Tubarão river estuary in May 2015. We sampled two estuarine areas (upper and lower), and in each zone were sampled six points composed of two replicas, one sampled in sandy bottom and the other in muddy bottom. Samples of benthic macroinvertebrates and estuarine environmental variables were collected. Environmental drivers of the benthic macroinvertebrate community were determined by Distance-based Linear Models analysis. The contribution of individual species to the dissimilarity between the areas and substrate types were determined by analysis of the percentage of similarity. Results: The composition of benthic macroinvertebrate community differed between the upper and lower areas, although it was similar between the muddy and sandy bottoms. The variation in the benthic community between areas was mainly related to the influence of salinity in the upper area. In the lower area, the variation of the macroinvertebrates was related to salinity, associated with other variables in the sandy (temperature, turbidity and dissolved oxygen) and muddy (temperature, total dissolved solids and dissolved oxygen) substrates. Taxa which contributed most to the dissimilarity between the upper and lower areas were Nereididae (17.89\%), Anomalocardia brasiliana (15\%) and Cirratulidae (10.43\%). Conclusions: Salinity was the main driver of the structural aspects of the benthic macroinvertebrate community in the upper area of the estuary, although in the lower area a set of variables have structured benthic macroinvertebrates in the hypersaline estuary studied. In addition, the largest mangrove cover and less influence of the tide, may have favored the greater abundance of macroinvertebrates in the upper area.
\end{abstract}

Keywords: negative estuary; benthic macrofauna; Polychaeta; Bivalvia; mangrove.

Resumo: Introduçáo: A comunidade de macroinvertebrados bentônicos estuarina varia espacialmente em resposta a mudanças nas variáveis ambientais nesses ecossistemas. $\mathrm{O}$ entendimento dessa variabilidade auxilia o conhecimento dos mecanismos estruturadores dessas comunidades. 
Objetivo: Avaliar os aspectos estruturais da comunidade de macroinvertebrados bentônicos em um estuário hipersalino, e relacionar as variáveis ambientais que atuam sobre a estrutura da comunidade ao longo do estuário. Métodos: O estudo foi realizado no estuário do Rio Tubarão em maio de 2015. Foram amostradas duas zonas do estuário (superior e inferior), e em cada zona foram amostrados seis pontos compostos de duas réplicas, uma réplica amostrada em substrato arenoso e a outra em substrato lamoso. Foram coletadas amostras de macroinvertebrados bentônicos e das variáveis ambientais do estuário. Os fatores direcionadores da comunidade de macroinvertebrados bentônicos foram determinados através da análise de Modelo Linear baseado na Distância e a contribuição das espécies para similaridade e dissimilaridade entre as áreas e tipos de substrato, através de análises de porcentagem de similaridade. Resultados: A composiçấo da comunidade de macroinvertebrados bentônicos divergiu entre as áreas superior e inferior, embora tenha sido semelhante entre os substratos lamoso e arenoso. A variação da comunidade entre as áreas foi principalmente relacionada à influência da salinidade, na área superior, e pela salinidade associada a outras variáveis no substrato arenoso (temperatura, turbidez e oxigênio dissolvido) e lamoso (temperatura, sólidos totais dissolvidos e oxigênio dissolvido) da área inferior. Os táxons que contribuíram para dissimilaridade entre as áreas superior e inferior foram Nereididae (17,89\%), Anomalocardia brasiliana (15\%) e Cirratulidae $(10,43 \%)$. Conclusóes: A salinidade foi a principal variável direcionadora dos aspectos estruturais da comunidade de macroinvertebrados bentônicos na área superior do estuário, embora na área inferior um conjunto de variáveis estruturaram a macrofauna bentônica no estuário hipersalino estudado. Além disso, a cobertura de mangue e menor influência da maré, pode ter favorecido a maior abundância de macroinvertebrados na área superior.

Palavras-chave: estuário negativo; macrofauna bentônica; Polychaeta; Bivalvia; manguezal.

\section{Introduction}

Estuaries are highly productive coastal ecosystems (Kennish, 2002), and its dynamics is related to the interactions among oceans, freshwater, land and atmosphere (Day et al., 2012). The dynamics of estuaries promotes a high complexity and heterogeneity of habitats, so that the community that persists exhibits unique characteristics (Laegdsgaard \& Johnson, 2001).

Based on salinity, estuaries are classified as inverse (negative), positive or neutral (Pritchard, 1952). Negative estuaries have a salinity that increases upstream because evaporation exceeds rainfall and the amount of freshwater input from the river is too small to compensate for the difference (Savenije, 2005). According to Savenije (2005), these estuaries occur in arid and semi-arid climates and are characterized by the occurrence of salt flats (salinas). These conditions can cause maximum salinity, also called hypersalinity (Valle-Levinson, 2010).

In estuarine ecosystems, a number of environmental factors predict the distribution of biological communities (Wells, 1961; Costa-Dias et al., 2010) and recent studies have highlighted the salinity as the main factor structuring these communities (Josefson \& Goke, 2013; Blanchet et al., 2014). Benthic macroinvertebrates are distributed along the salinity gradient of the estuaries and the fauna is primarily composed of polychaetes, molluscs and crustaceans
(Tweedley et al., 2012). These organisms play critical roles in these ecosystems acting in the energy flow to higher trophic levels and in the decomposition of organic matter (Abílio et al., 2007), among other functions in the ecosystem. The distribution of benthic macroinvertebrate community has been studied, in order to understand the functioning of the estuarine ecosystem and understanding the mechanisms structuring the benthic macroinvertebrate community (Hewitt et al., 2005; Lima et al., 2013; Blanchet et al., 2014).

The distribution pattern of the benthic macroinvertebrate community has been widely described in ecosystems where salinity levels increase progressively from upstream to downstream (positive estuarine ecosystems) in temperate regions (Josefson \& Hansen, 2004; Bleich et al., 2011; Josefson \& Goke, 2013), with less focus on tropical estuaries (Barros et al., 2008). However, very little has been described for hypersaline estuaries, particularly for benthic macroinvertebrates.

In that perspective, this study aims to evaluate the distribution pattern of the benthic macroinvertebrate community in a hypersaline estuary of the littoral semiarid in northeastern Brazil, and identify which environmental variables drive the structure of this community. We tested the hypothesis that salinity is the environmental variable that has the most influence on the structure of the benthic macroinvertebrate community acting in the selection of species along the estuary. 


\section{Material and Methods}

\subsection{Study area}

The study site was the Tubarâo River, located in the city of Macau, northern coast of the state of Rio Grande do Norte, Northeastern Brazil $\left(5^{\circ} 05^{\prime} 37^{\prime \prime} \mathrm{S}, 36^{\circ} 32^{\prime} 21^{\prime \prime} \mathrm{W}\right)$ (Figure 1). The study area is included within the limits of Ponta do Tubarão Sustainable Development Reserve, a protected area of sustainable use managed by the state government.

Tubarão River is considered a sea arm that has penetrated the continent and currently extends for $10 \mathrm{~km}$ being fed by the freshwater from groundwater and low rainfall occurring in the region (Queiroz \& Dias, 2014) and subject to periodic water inputs from the sea by strong tidal currents (Dias et al., 2007).

In the city of Macau, the rainy season is 3-4 months (February to May), and the dry season extends for 8 or 9 months (June to January) (INMET, 2015). In 2015, the average rainfall between January and May was only $58 \mathrm{~mm}$ (INMET, 2015). The average wind speed in the region is $20.5 \mathrm{~km} / \mathrm{h}$, characterizing them as the stronger winds of northeastern Brazil (INMET, 2010).

Tubarão River is bordered by mangrove vegetation and its surroundings has a variety of ecosystems such as salt marshes, Caatinga vegetation, mobile and fixed dune fields and cliffs (Dias et al., 2007).

\subsection{Sampling procedures}

Samples were collected in May 2015. Samples were collected in two areas: 1) the upper area, upstream, whose margins had dense mangrove vegetation and was subject to minor wave action, and 2) the lower area, closer to the sea, whose mangrove vegetation was scarce and was subject to strong wave action. Six sample points were determined in each area with two replicates, visually selecting a replica with the sandy substrate and the other replica with muddy substrate. In total 24 samples were taken, 12 in the upper area, and 12 on the lower area, six of the muddy substrate and six of the sandy substrate in each area. The muddy and sandy substrates would be found at different

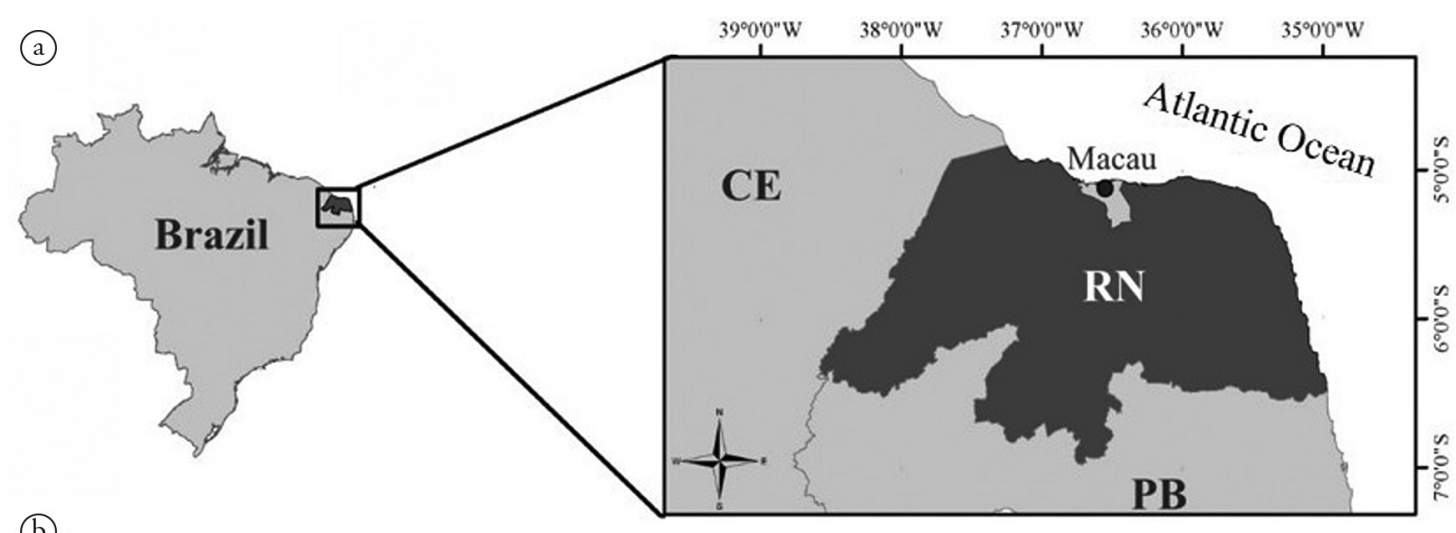

(b)

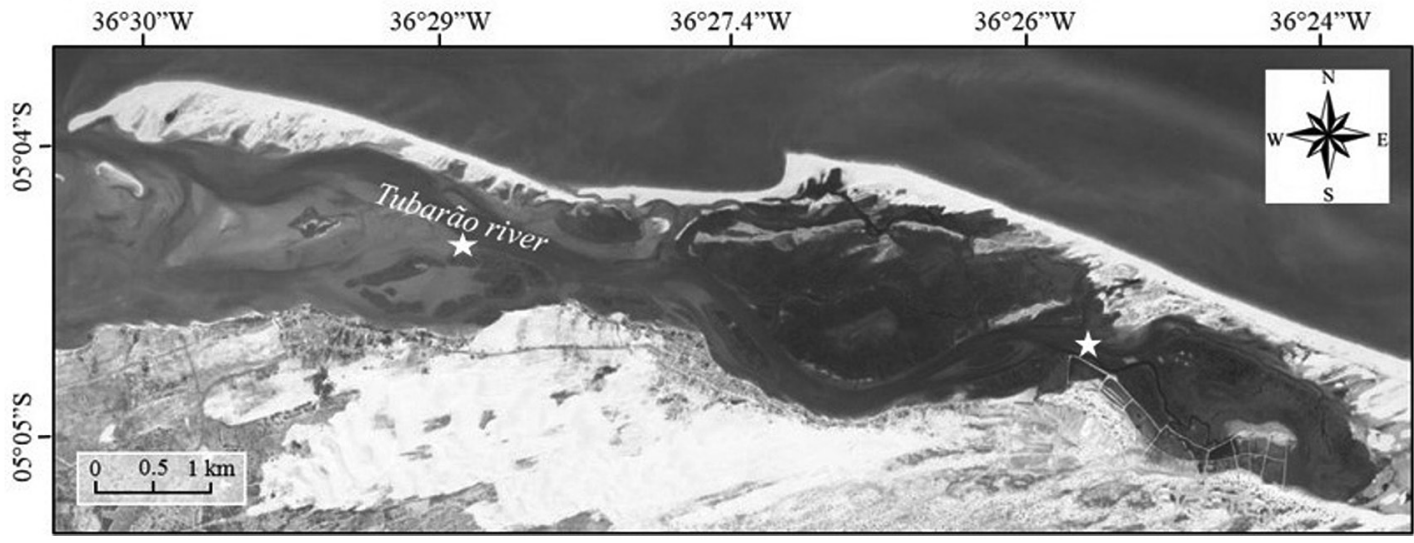

Figure 1. (a) Location of the study area in the State of Rio Grande do Norte, Northeastern Brazil; (b) Partial view of the Tubarão River. Legend: $\star$ indicates the sampling areas. 
depths. Therefore, the types of substrate were sampled at $15 \mathrm{~cm}$ (muddy substrate) and $80 \mathrm{~cm}$ (sandy substrate).

Sediment samples to macrofaunal removal were collected with a cylindrical corer (area: $16.67 \mathrm{~cm}^{2}$ ) to obtain a portion of $5 \mathrm{~cm}$ in height from the sediment for each sample. Sediment washing for separation of benthos was performed in the field using local water under a sieve with mesh of $500 \mu \mathrm{m}$. Benthic mollusks were identified to genus or species, and the polychaetes were identified to the taxonomic level of family using specialized literature (e.g., Amaral \& Nonato, 1996; Amaral et al., 1998; Tunnell Junior et al., 2010).

Physical and chemical parameters were obtained during high tide through multiparameter sonde Horiba model. The measured variables were salinity, temperature $\left({ }^{\circ} \mathrm{C}\right), \mathrm{pH}$, conductivity $\left(\mu \mathrm{S} / \mathrm{cm}^{2}\right)$, turbidity, dissolved oxygen $\left(\mathrm{mg} / \mathrm{L}^{-1}\right)$ and total dissolved solids (TDS).

\subsection{Data analysis}

To assess significant differences in the composition of benthic macroinvertebrate community among the areas and types of substrates sampled, Permutational Multivariate Analyzes of Variance were performed (PERMANOVA) (Anderson et al., 2008). For this, it was established two factors: area (two levels: upper and lower) and substrate (two levels: sandy and muddy). It was considered significant the differences when $\alpha \leq 0,05$, using 9999 permutations. The data were transformed into square root and Bray-Curtis was used as a measure of dissimilarity (Anderson, 2001; Anderson et al., 2008).

To assess significant differences for each environmental variable between the upper and lower areas, PERMANOVA univariate analyzes were performed considering significant differences when $\alpha \leq 0.05$, using 9999 permutations. In this case, the environmental data were transformed into $\log (\mathrm{x}+1)$ and the Euclidean distance coefficient was used. To determine if one or more environmental variables were drivers of the structural aspects of the benthic macroinvertebrate community in different areas (upper and lower) and substrate types (sandy and muddy), Linear Distance-based Models (DistLM) analyzes were performed through a dissimilarity matrix, using 9999 permutations (Legendre \& Anderson, 1999).

Visualization of the spatial distribution of the environmental variables and abundance of benthic macroinvertebrate community between areas (levels: upper and lower) and type of substrate (levels: sandy and muddy) was obtained by Non-metric Multi-Dimensional Scaling (NMDS) (Clarke \& Gorley, 2006).

The species that most contributed to the similarity and dissimilarity between as areas and substrate types were determined by a similarity percentage analysis (SIMPER).

All statistical analyzes were performed on PRIMER 6 \& PERMANOVA+ software (Systat Software, Cranes Software International Ltd. 2008).

\section{Results}

A total of 301 individuals, distributed in 23 taxa of Polychaeta and Mollusca, represented the benthic macroinvertebrate community. The occurrence of $221(73.42 \%)$ individuals in the upper area was recorded, the most abundant being polychaetes Nereididae (28.50\%), the bivalve Anomalocardia brasiliana (Gmelin, 1791) (27.60\%) and polychaetes Cirratulidae (23.98\%). In the lower area, 80 individuals (26.57\%) were recorded, with greater representation of $A$. brasiliana (20\%), Neritina virginea (Linnaeus, 1758) (16.25\%) and Cirratulidae (12.5\%).

The analysis PERMANOVA showed that the composition of benthic macroinvertebrate community significantly differed between the upper and lower areas (Pseudo- $\mathrm{F}_{1.23}=2.6574 ; \mathrm{p}=0.001$ ), however, did not differ between the substrate types (Pseudo- $\mathrm{F}_{1.23}=0.98731 ; \mathrm{p}=0.4587$ ).

The variables temperature (Pseudo- $\mathrm{F}_{1.11}=9.0924$; $\mathrm{p}=0.0155), \mathrm{pH}$ (Pseudo- $\mathrm{F}_{1.11}=40.645 ; \mathrm{p}=0.0029$ ) and dissolved oxygen (Pseudo- $\mathrm{F}_{1.11}=34.683$; $\mathrm{p}=0.0017$ ) were different between the upper and lower areas, while the electrical conductivity (Pseudo- $\mathrm{F}_{1.11}=0.90178 ; \mathrm{p}=0.508$ ), turbidity (Pseudo- $\left.\mathrm{F}_{1.11}=4.3321 ; \mathrm{p}=0.065\right)$, total dissolved solids (Pseudo- $\mathrm{F}_{1.11}=2.1337 ; \mathrm{p}=0.2547$ ) and salinity (Pseudo-F ${ }_{1.11}=1.2967 ; \mathrm{p}=0.30$ ) did not differ significantly between the upper and lower areas (Table 1). The DistLM analysis showed that salinity was the variable that most influenced the distribution of the benthic macroinvertebrate community in the upper area for both types of substrate, sandy (R2=0.35206) and muddy $(\mathrm{R} 2=0.24356)$. In the lower area the variables that explain the community distribution in sandy substrate were temperature, turbidity, dissolved oxygen and salinity (R2=0.87923). For the muddy substrate, temperature, total dissolved solids, dissolved oxygen and salinity were the variables 
that better explained the community distribution (R2=0.95456).

When considering the abundance of benthic macroinvertebrate community, NMDS analysis showed no grouping between the sampling points of the upper and lower areas (Figure 2a), or between the muddy and sandy substrates (Figure 2b). The NMDS, showed total aggregation among environmental variables between areas (Figure 3a) and substrate types (Figure $3 b$ ).
The results of SIMPER showed that the taxa that most contributed to the similarity of the upper area were Nereididae (34.49\%), A. brasiliana (31.43\%) and Goniadidae (14.44\%). On the other hand, to the lower area, the taxa that most contributed were A. brasiliana (65.73\%), Scoloplos (12.9\%) and Neritina virginea (18.8\%). The community dissimilarity between the upper and lower areas was due to the taxa Nereididae (17.89\%), A. brasiliana (15\%) and Cirratulidae (10.43\%).

Table 1. Environmental variables (mean and standard deviation) measured at the upper and lower area of the Tubarão River, State of Rio Grande do Norte, Northeastern Brazil.

\begin{tabular}{|c|c|c|c|c|}
\hline & \multicolumn{2}{|c|}{ Upper } & \multicolumn{2}{|c|}{ Lower } \\
\hline & Sandy & Muddy & Sandy & Muddy \\
\hline Water temperature $\left({ }^{\circ} \mathrm{C}\right)$ & $28.50 \pm 0.69$ & $29.58 \pm 0.39$ & $29.82 \pm 0.19$ & $30.44 \pm 0.30$ \\
\hline $\mathrm{pH}$ & $8.81 \pm 0.07$ & $8.92 \pm 0.10$ & $9.14 \pm 0$ & $9.14 \pm 0.01$ \\
\hline Conductivity $\left(\mu \mathrm{S} / \mathrm{cm}^{-1}\right)$ & $78.03 \pm 0.35$ & $72.2 \pm 7.2$ & $76.53 \pm 0.77$ & $78.06 \pm 0.49$ \\
\hline Turbidity (NTU) & $13.73 \pm 1.98$ & $24.33 \pm 11.86$ & $23.06 \pm 4.38$ & $45.53 \pm 25.29$ \\
\hline Dissolved oxygen (\%) & $67 \pm 9.60$ & $84.93 \pm 9.21$ & $114.26 \pm 3.05$ & $115.10 \pm 3.46$ \\
\hline Total Dissolved Solids (mg/L-1) & $46.83 \pm 0.15$ & $41.26 \pm 4.70$ & $45.80 \pm 0.52$ & $47.56 \pm 1.15$ \\
\hline Salinity (\%) & $54.4 \pm 0.20$ & $53.50 \pm 1.66$ & $49.53 \pm 5.31$ & $54.23 \pm 0.40$ \\
\hline
\end{tabular}
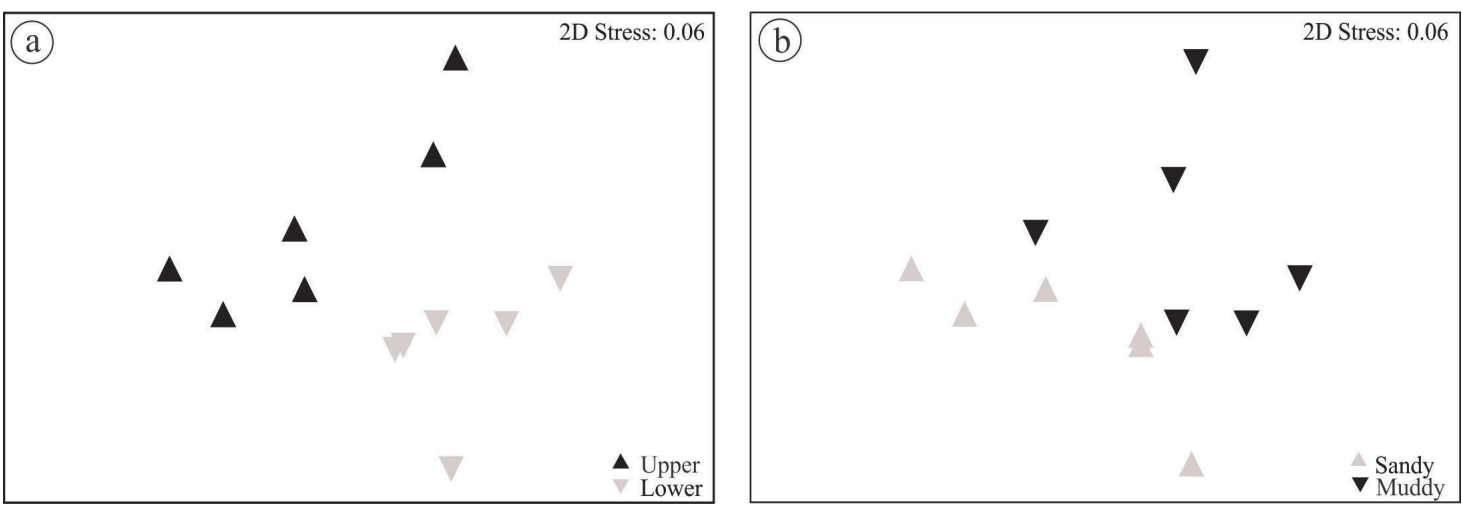

Figure 2. Multidimensional scaling ordination model of environmental parameters obtained from Tubarão river (Macau, Rio Grande do Norte). (a) Upper and lower areas of the estuary; (b) Sandy and muddy substrates.
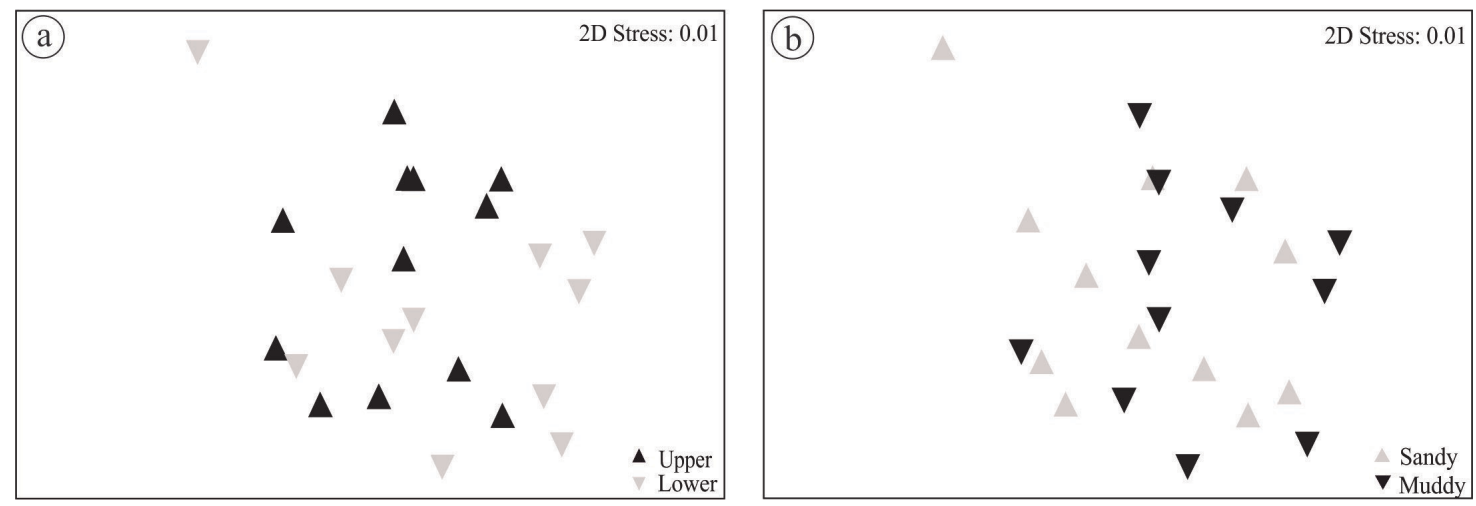

Figure 3. Multidimensional scaling ordination model of abundance of individuals at Tubarão river (Macau, Rio Grande do Norte) in relation to: (a) upper and lower areas of the estuary; and (b) sandy and muddy substrates. 


\section{Discussion}

Our results showed that the structure of the benthic macroinvertebrate community varied between the upper and lower areas, with a spatial segregation of their sampling points. The environmental variables influence the distribution patterns of the benthic macroinvertebrate community between areas. However, the type of substrate (sandy and muddy) was not a structuring factor for the macrofauna.

Temperature, dissolved oxygen and $\mathrm{pH}$ were different among the areas when the environmental variables we relate to the abundance of the community, but only salinity was the variable that directed the structural aspects of the macrobenthic community in the upper area in both types of substrate. In this case, the greater abundance of macroinvertebrate community recorded in the upper area could be related to the favoring of euryhaline species which, under extreme salinity conditions can perform osmoregulation (Teske \& Wooldridge, 2001).

Besides the influence of salinity, the greater abundance of benthic fauna in the upper area, can also be related to estuarine features such as vegetation in the surrounding of the ecosystem and the influence of waves, which differ between the upper and lower areas. The upper area shows the margins with dense mangrove vegetation and is subject to less influence of wave action. These characteristics can facilitate the development of suitable environments for the establishment and development of the species.

In the lower area, salinity also influence the community distribution, but in combination with other environmental variables. Although salinity remained very high (ranging from 49.53 to 54.4 ) in the river shark it was not observed an evident salinity gradient. The lower abundance of the community in this area could be related to the stress resulting from the waves action, which acts as a physiological barrier in the survival and reproduction of the species, and the absence of mangrove vegetation in this area. This process results in the selection of species with functional and morphological characteristics to persist in this area. The inverse hypersaline gradient in the estuary of the Tubarão River was identified by Queiroz \& Dias (2014), where it influenced the community distribution. The increase in the levels of dissolved oxygen in the lower area also affected the abundance of benthic macroinvertebrates. In an inverse way, Kolar \& Rahel (1993) emphasized that the decrease in oxygen content affects the distribution and development of benthic organisms in response to hypoxia.

The species $A$. brasiliana, was that contributes most to similarity between the upper and lower areas. This fact is due to its ability to tolerate high salinity along the estuary (Silva et al., 2005). According to Rodrigues et al. (2010), A. brasiliana is an euryhaline species, once it can be found in salinities varying from 10 to 49 . However, Barroso \& Matthews-Cascon (2009) found that A. brasiliana presents relative limitation to very low salinity, since the species has only occurred in points with great marine influence, not occurring in areas where salinity was less than 30 .

The occurrence of the gastropod Neritina virginea in the upper area, demonstrates its capacity to tolerate high salinity as demonstrated by Cruz-Neta \& Henry-Silva (2013), in which the species was found in salinities until 49. Furthermore, this species is one of the most conspicuous in estuaries along the Brazilian coast (Rios, 2009).

Despite the abundance did not significantly differ between the sandy and muddy substrates in the study area, other studies show that sediment composition is a major factor in structuring the macrofauna (e.g., Hewitt et al., 2005; Lima et al., 2013) since these organisms have benthic life mode. In this context, we suggest that future studies should be carried out using precise techniques for sediment classification.

We conclude that the structural aspects of the benthic macroinvertebrate community varied between the upper and lower areas, and that this change was mainly related to the influence of salinity (in the upper area), and the salinity in combination with other variables, especially the dissolved oxygen (in the lower area). In addition, mangrove vegetation and influence of the waves acted in structuring the benthic macroinvertebrates.

\section{Acknowledgements}

The authors thank the Programa de Pós-graduação em Ecologia e Conservação of Universidade Estadual da Paraíba for funding this research and for logistical support during fieldwork. Special thanks to Luis Carlos (Pop) and Daison for help with fieldwork and Pousada do Élio, Dalci and Belo for logistical support in laboratory work.

\section{References}

ABÍLIO, F.J.P., RUFFO, T.L.M., SOUZA, A.H.F.S., FLORENTINO, H.S., OLIVEIRA JUNIOR, E.T., MEIRELES, B.N. and SANTANA, A.C.D. 
Macroinvertebrados aquáticos como bioindicadores de qualidade ambiental de corpos aquáticos da Caatinga. Oecologia Brasiliensis, 2007, 11(3), $397-$ 409. http://dx.doi.org/10.4257/oeco.2007.1103.09.

AMARAL, A.C. and NONATO, E.F. Annelida Polychaeta: características, glossário e chaves para famílias e gêneros da costa brasileira. Campinas: Editora da UNICAMP, 1996, 124 p.

AMARAL, A.C., MORGADO, E.H. and SALVADOR, L.B. Poliquetas bioindicadores de poluição orgânica em praias paulistas. Revista Brasileira de Biologia, 1998, 58(2), 307-316. PMid:9697655.

ANDERSON, M.J. A new method for non-parametric multivariate analysis of variance. Austral Ecology, 2001, 26(1), 32-46.

ANDERSON, M.J., GORLEY, R.N. and CLARKE, K.R. PERMANOVA + for PRIMER: guide to software and statistical methods. Plymouth: PRIMER-E, 2008.

BARROS, F., HATJE, V., FIGUEIREDO, M.B., MAGALHAES, W.F., DOREA, H.S. and EMÍDIO, E.S. The structure of the benthic macrofaunal assemblages and sediments characteristics of the Paraguaçu estuarine system, NE, Brazil. Estuarine, Coastal and Shelf Science, 2008, 78(4), 753-762. http://dx.doi.org/10.1016/j.ecss.2008.02.016.

BARROSO, C.X. and MATTHEWS-CASCON, H. Distribuição espacial e temporal da malacofauna no estuário do Rio Ceará, Ceará, Brasil. Pan-American Journal of Aquatic Sciences, 2009, 4(1), 79-86.

BLANCHET, H., GOUILLIEUX, B., ALIZIER, S., AMOUROUX, J.-M., BACHELET, G., BARILLÉ, A.-L., DAUVIN, J.-C., DE MONTAUDOUIN, X., DEROlEZ, V., DESROY, N., GRALL, J., GRÉMARE, A., HACQUEBART, P., JOURDE, J., LABRUNE, C., LAVESQUE, N., MEIRLAND, A., NEBOUT, T., OLIVIER, F., PELAPRAT, C., RUELLET, T., SAURIAU, P.-G. and THORIN, S. Multiscale patterns in the diversity and organization of benthic intertidal fauna among French Atlantic estuaries. Journal of Sea Research, 2014, 90, 95-110. http://dx.doi.org/10.1016/j.seares.2014.02.014.

BLEICH, S., POWILLEIT, M., SEIFERT, T. and GRAF, G. Beta-diversity as a measure of species turnover along the salinity gradient in the Baltic Sea, and its-consistency with the Venice System. Marine Ecology Progress Series, 2011, 436, 101-118. http:// dx.doi.org/10.3354/meps09219.

CLARKE, K.R. and GORLEY, R.N. Primer v6: user manual tutorial. Plymouth: PRIMER-E, 2006, pp. 75-88

COSTA-DIAS, S., FREITAS, V., SOUSA, R. and ANTUNES, C. Factors influencing epibenthic assemblages in the Minho Estuary. Marine Pollution, 2010, 61(4-6), 240-246. http://dx.doi.org/10.1016/j. marpolbul.2010.02.020. PMid:20347101.
CRUZ-NETA, C.P. and HENRY-SILVA, G.G. Aspectos da dinâmica populacional do gastrópode Neritina virginea em regiáo estuarina do Rio Grande do Norte, Brasil. Boletim do Instituto de Pesca, Sao Paulo, 2013, 39(1), 1-14.

DAY, J.W., YÁÑEZ-ARANCIBIA, A., KEMP, W.M. and CRUMP, B.C. Introduction to estuarine ecology. In J.W. DAY, B.C. CRUMP, W.M. KEMP and A. YÁÑEZ-ARANCIBIA, eds. Estuarine ecology. New Jersey: Wiley-Blackwell, 2012, pp. 327-325.

DIAS, T.L.P., ROSA, R.S. and DAMASCENO, L.C.P. Aspectos socioeconômicos, percepção ambiental e perspectivas das mulheres marisqueiras da Reserva de Desenvolvimento Sustentável Ponta do Tubarão (Rio Grande do Norte, Brasil). Gaia Scientia, 2007, 1(1), 25-35.

HEWITT, J.E., THRUSH, S.F., HALLIDAY, J. and DUFFY, C. The importance of small-scale habitat structure for maintaining beta diversity. Ecology, 2005, 86(6), 1619-1626. http://dx.doi. org/10.1890/04-1099.

INSTITUTO NACIONAL DE METEOROLOGIA - INMET. [online]. Brasília, 2010 [viewed 12 Oct. 2015]. Available from: www.inmet.gov.br

INSTITUTO NACIONAL DE METEOROLOGIA - INMET. [online]. Brasília, 2015. [viewed 12 Oct. 2015]. Available from: www.inmet.gov.br

JOSEFSON, A.B. and GÖKE, C. Disentangling the effects of dispersal and salinity on beta diversity in estuarine benthic invertebrate assemblages. Journal of Biogeography, 2013, 40(5), 1000-1009. http://dx.doi. org/10.1111/jbi.12047.

JOSEFSON, A.B. and HANSEN, J.L.S. Species richness of benthic macrofauna in Danish estuaries and coastal areas. Global Ecology and Biogeography, 2004, 13(3), 273-288. http://dx.doi.org/10.1111/j.1466822X.2004.00091.x.

KENNISH, M.J. Environmental threats and environmental future of estuaries. Environmental Conservation, 2002, 29(1), 78-107. http://dx.doi. org/10.1017/S0376892902000061.

KOLAR, C.S. and RAHEL, F.J. Interaction of a biotic factor (predator presence) and an abiotic factor (low oxygen) as an influence on benthic invertebrate communities. Oecologia, 1993, 95(2), 210-219. http://dx.doi.org/10.1007/BF00323492.

LAEGDSGAARD, P. and JOHNSON, C. Why do juvenile fish utilize mangrove habitats? Journal of Experimental Marine Biology and Ecology, 2001, 257(2), 229-253. http://dx.doi.org/10.1016/S00220981(00)00331-2. PMid:11245878.

LEGENDRE, P. and ANDERSON, M.J. Distancebased redundancy analysis: testing multispecies responses in multifactorial ecological experiments. Ecological Monographs, 1999, 69(1), 1-24. http:// 
dx.doi.org/10.1890/0012-9615(1999)069[0001:DB RATM]2.0.CO;2.

LIMA, F.B., SCHÄFER, A.E. and LANZER, R.M. Diversity and spatial and temporal variation of benthic macroinvertebrados with respect to the trophic state of Lake Figueira in the South Brazil. Acta Limnologica Brasiliensia, 2013, 25(4), 429-441. http://dx.doi. org/10.1590/S2179-975X2013000400008.

PRITCHARD, D.W. Estuarine hydrography. Advances in Geophysics, 1952, 1, 243-280. http://dx.doi. org/10.1016/S0065-2687(08)60208-3.

QUEIROZ, R.N.M. and DIAS, T.L.P. Molluscs associated with the macroalgae of the genus Gracilaria (Rhodophyta): importance of algal fronds as microhabitat in a hypersaline mangrove in Northeastern Brazil. Revista Brasileira de Biologia, 2014, 74(3), 52-63, Supplement 1. http://dx.doi. org/10.1590/1519-6984.20712. PMid:25627366.

RIOS, E.C. Compendium of Brazilian Sea Shells. Rio Grande: FURG, 2009, 676 p.

RODRIGUES, A.M.L., BORGES-AZEVEDO, C. and HENRY-SILVA, G.G. Aspectos da biologia e ecologia do molusco bivalve Anomalocardia brasiliana (Gmelin, 1791) (Bivalvia, Veneridae). Brazilian Journal of Biosciences, 2010, 8(4), 377-383.

SAVENIJE, H.H.G. Salinity and tides in alluvial estuaries. Amsterdam: Elsevier Science, 2005, 208 p.

SILVA, E., SOARES-GOMES, A., FERNANDES, F. and ABREU, C. Sandy beach macrobenthos assemblages at a hypersaline coastal lagoon, Lagoa de Araruama, RJ, Brazil. Journal of Coastal Research, 2005, SI(42), 265-270.

TESKE, P.R. and WOOLDRIDGE, T. A comparison of the macrobenthic faunas of permanently open and temporarily open/closed South African estuaries. Hydrobiologia, 2001, 464(1-3), 227-243. http:// dx.doi.org/10.1023/A:1013995302300.

TUNNELL JUNIOR, J.W., ANDREWS, J., BARREA, N.C. and MERETZSOHN, F. Encyclopedia of Texas Seashells: identification, ecology, distribution, and history. Texas: A\&M University Press, 2010, 512 p.

TWEEDLEY, J.R., WARWICK, R.M., VALESINI, F.J., PLATELL, M.E. and POTTER, I.C. The use of benthic macroinvertebrates to establish a benchmark for evaluating the environmental quality of microtidal, temperate southern hemisphere estuaries. Marine Pollution Bulletin, 2012, 64(6), 1210-1221. http:// dx.doi.org/10.1016/j.marpolbul.2012.03.006. PMid:22482867.

VALLE-LEVINSON, A. Definition and classification of estuaries: contemporary issues in estuarine physics. New York: Cambridge University Press, 2010, 327 p. http://dx.doi.org/10.1017/CBO9780511676567.

WELLS, H.W. The Fauna of oyster beds, with special reference to the salinity factor. Ecological Monographs, 1961, 31(3), 239-266. http://dx.doi. org/10.2307/1948554.

Received: 12 October 2015 Accepted: 06 May 2016 